\title{
Health Risk Assessment of Mercury Contaminated Forest Mushrooms from the Czech and Slovak Republics
}

\author{
Andrea Ridošková ${ }^{1,2}$, Klaudia Dudášová1, Pavlína Pelcová1, Jana Hrachovinová ${ }^{1}$ \\ ${ }^{1}$ Department of Chemistry and Biochemistry, Mendel University in Brno \\ Zemedelska 1, CZ-61300, Brno, Czech Republic \\ andrea.ridoskova@mendelu.cz; klaudia.dudasova@mendelu.cz; pavlina.pelcova@mendelu.cz \\ jana.hrachovinova@mendelu.cz \\ ${ }^{2}$ Central European Institute of Technology CEITEC MENDELU, Mendel University in Brno \\ Zemedelska 1, CZ-61300, Brno, Czech Republic
}

\begin{abstract}
Mercury and its compounds belong to the most toxic substances in the environment and their exposure represents a significant worldwide health issue. Due to the extensive historical mining and metallurgical activities in the Czech and Slovak Republics, several localities with high metal contamination are located here. For monitoring of mercury contamination in edible mushroom species, two very contaminated localities ("Brdy" in the Czech Republic and "Spišská nová ves" in Slovakia) and eight non-polluted localities were chosen. The highest contents of mercury were found in wild-grown Agaricus bisporus ( $7.68 \pm 0.43 \mathrm{mg} \cdot \mathrm{kg}^{-1} \mathrm{DW}$ ) and Russula integra $\left(9.52 \pm 0.46 \mathrm{mg} \mathrm{kg}^{-1} \mathrm{DW}\right)$. The highest hazard indexes were calculated for these samples, too. The highest bioconcentration factor was calculated for Boletus reticulatus.
\end{abstract}

Keywords: Mercury, mushrooms, soil, atomic absorption spectrometry.

\section{Introduction}

Mushrooms have become a very popular delicacy all over the world. Mushroom picking has become a highly valued recreational activity in the Czech and Slovak Republics. Most collected mushrooms are used for pickers' own consumption. Mushroom consumption in the Czech and Slovak Republics increases, mainly due to their beneficial effects on human health. Mushrooms are an important source of proteins, amino acids, minerals and also dietary fiber, which is recommended for many diets [1]. Mushrooms can either be seasonally harvested in forests or can be cultivated using special methods. The milkcaps (Lactarius spp.), brittlegills (Russula spp.), chanterelles (Cantharellus spp.), agarics (Agaricus spp.) and boletes (Boletus spp.) belong among the most common worldwide consumed and traded wild mushroom species [2]. Mercury is the most toxic heavy metal and is in the soil mainly due to pedogenetic processes and anthropogenic activities. Mushrooms gain from the soil the necessary nutrients for their growth, but also other substances such as heavy metals. The uptake of mercury by the mushrooms depends on the environmental conditions, physicochemical properties in soil and availability of metals to the mycelium. Due to the high total mercury content in some mushroom species, their intensive consumption can lead to dangerous levels of metal intake by humans and animals [3]. The aim of this work was to analyze the total mercury content in mushrooms from contaminated and non-polluted localities in the Czech Republic and Slovakia. By determining the mercury concentration in mushrooms, the potential toxicological risk for consumers can be assessed.

\section{Experimental}

\section{1. Sampling sites and mushroom species}

The mushroom samples were collected from two very contaminated localities (Brdy, Czech Republic (1) and Spišská nová ves, Slovakia (10) and from eight non-polluted localities (2-6) from the Czech Republic, (7-9) from Slovakia in 20172019. All sampling localities are mentioned in Figure 1. The locality of Jedová hora (Brdy, Czech Republic) (English translation - Poison hill) is one of three historical Czech deposits of cinnabar mining. The locality of Spišská nová ves (Slovakia) is significant due to extensive mining and metallurgical activities.

A total of 15 edible forest mushroom species were collected, all of which are mentioned in Figure 1.

2-7 pieces of each mushroom species, which were found on the appropriate sampling site were collected. 


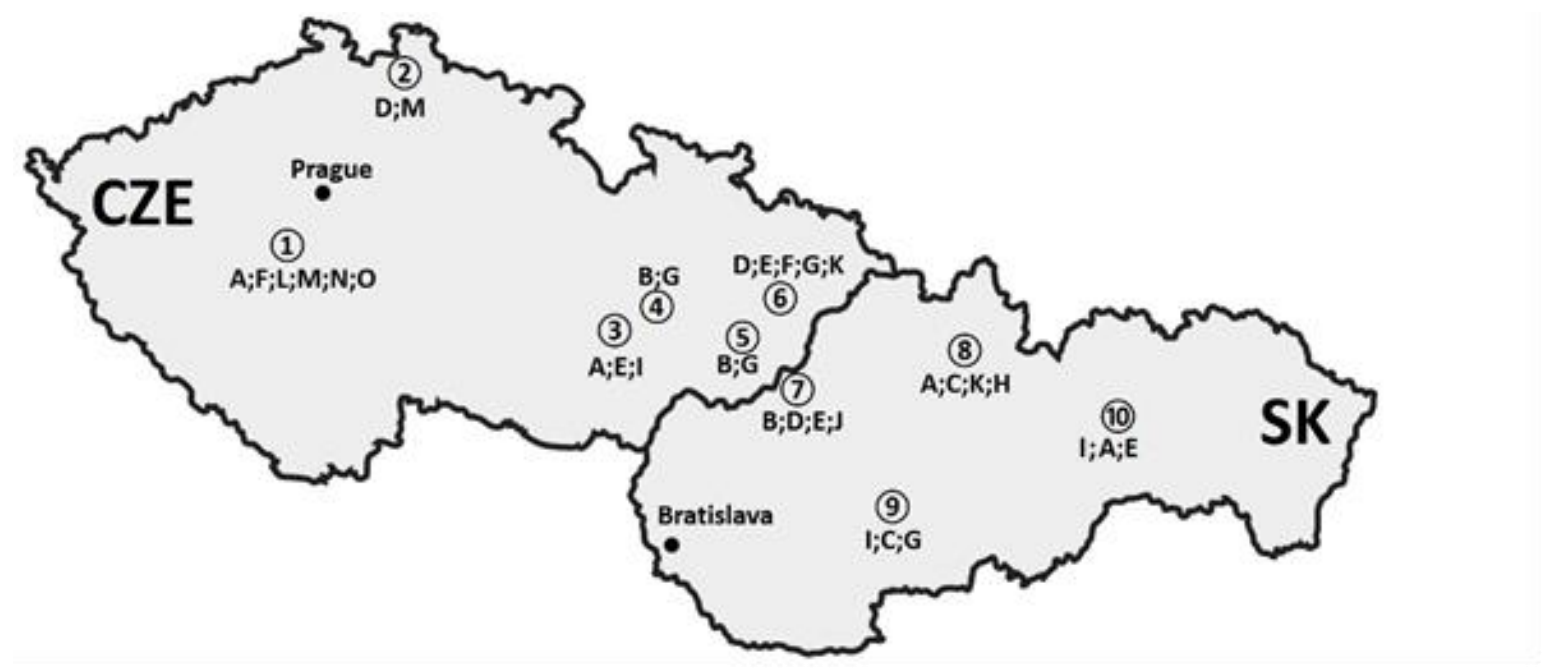

Fig. 1: Sampling sites in the Czech and Slovak Republics.

(samples of mushrooms: A - Macrolepiota procera; B - Pleurotus ostreatus; C - Boletus reticulatus; D - Boletus edulis; E - Boletus pinophilus; F - Neoboletus luridiformis; G - Leccinum scabrum; H - Cantharellus cibarius; I - Agaricus bisporus; J - Armillaria mellea; K - Boletus badiorufus; L - Amanita rubescens; M - Suillus grevillei; N - Lycoperdon molle, O Russula integra)

(sampling sites: Czech Republic (CZE): 1 - Brdy; 2 - Liberecko; 3 - CHKO Bobrava; 4 - Moravský kras; 5 - Zlínsko; 6 Vsetínsko. Slovakia (SK): 7 - Trenčín; 8 -Zuberec; 9 - Štiavnické vrchy; 10 - Spišská nová ves)

\section{2. Sample preparation}

All collected mushroom samples were thoroughly cleaned of small impurities and then dried to constant weight at $40{ }^{\circ} \mathrm{C}$ in drying oven (Ecocell, Fisher Scientific, Sweden). Dried mushroom samples were homogenized in a mortar. The soil was sampled in $5 \mathrm{~cm}$ to $15 \mathrm{~cm}$ depth after removing the surface layer of vegetation around the mushroom sample. The soil samples were sieved to exclude particles larger than $2 \mathrm{~mm}$ and then dried at $40{ }^{\circ} \mathrm{C}$ to constant weight.

\section{3. Analytical Procedures}

The atomic absorption spectrometry (AMA 254, Altec Praha, Czech Republic) was used for the determination of total mercury concentration in dried soil and mushroom samples. The determination is described in detail in our previous work [4].

\section{4. Calculation of bioconcentration factor and hazard index}

The bioconcentration factor (BCF) was calculated as the ratio of the concentration of mercury in mushrooms/concentration of mercury in soil [5]. For human risk assessment from mushrooms, a calculation of hazard index $(\mathrm{H})$ according to Kannan et al. was used [6]. The hazard index $(\mathrm{H})$ for the mercury is the ratio of the dose (D) to the upper level of daily mercury intake over a lifetime estimated to be without toxic effects (i.e., RfD). If the $\mathrm{H}$ value is less than 1, toxic effects are not expected to occur. PTWI (provisional tolerable weekly intake) for inorganic mercury has been established to $4 \mu \mathrm{gg}^{-1}$ [7].

\section{5. Statistical Analysis}

An ANOVA statistical method was used to finding statistically significant differences among individual mushroom species and software STATISTICA12 (Statsoft, Czech Republic) was used. For correlation analysis, Pearson's correlation coefficient was used. The statistical significance difference was declared for $\mathrm{p}$-value $<0.05$. 


\section{Results and Discussion}

\section{1. Total mercury content in mushroom samples}

A total of 98 samples were analyzed. The most found mushrooms were from the Boletaceae family (B. reticulatus, $B$. B. edulis, B. Badiorufus), which are considered as very tasty mushrooms and they are abundantly collected by mushroom pickers in the Czech and Slovak Republics [8]. Conversely, an Agaricus bisporus were the least founded mushrooms there. The highest concentration of mercury in Slovakia was measured in the Agaricus bisporus $\left(7.68 \pm 0.43 \mathrm{mg} \mathrm{kg}^{-1} \mathrm{DW}\right)$ from Spišská nová ves locality. In Czech Republic, the highest mercury concentrations were found in the Lycoperdon molle (5.60 $\left.\pm 0.49 \mathrm{mg} \mathrm{kg}^{-1} \mathrm{DW}\right)$, Russula integra $\left(9.52 \pm 0.46 \mathrm{mg} \mathrm{kg}^{-1} \mathrm{DW}\right)$ and Macrolepiota procera $\left(6.12 \pm 0.53 \mathrm{mg} \mathrm{kg}^{-1} \mathrm{DW}\right)$ from Brdy locality (Fig.2). These mushroom samples exceeded the maximum limit (5 mg Hg kg-1 DW) set by previously valid Decree of the Ministry of Health (CZ) No. 298/1997.

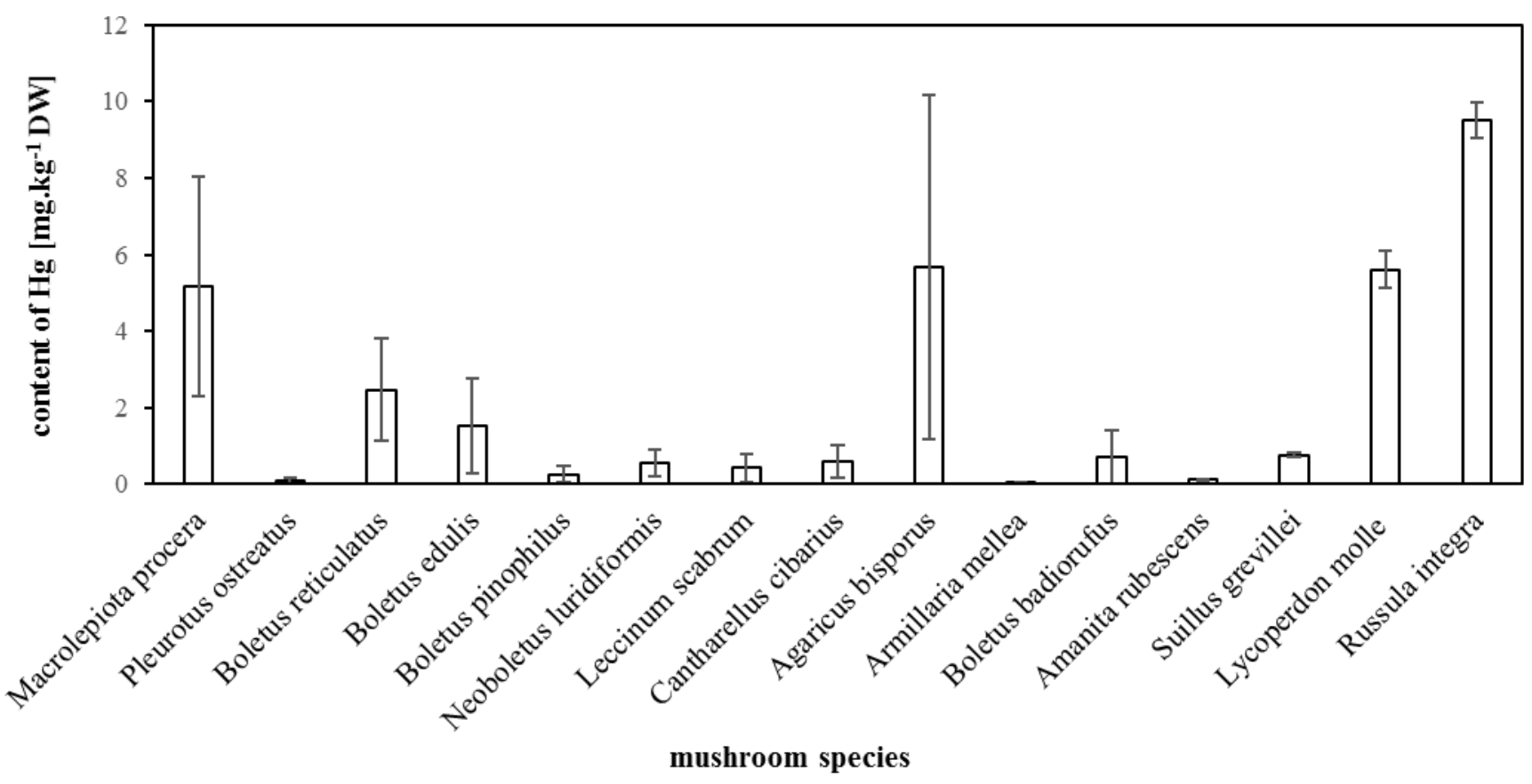

Fig. 2: Mercury concentration in mushroom species.

\section{2. Total mercury content in soil samples}

The highest mercury contents were determined in forest soil samples in Brdy locality (around Poison hill) (1.39-30.85 $\left.\mathrm{mg} \mathrm{kg}^{-1}\right)$. In the Spišská nová ves locality, there was determined $0.98-5.84 \mathrm{mg} \mathrm{kg}^{-1} \mathrm{Hg}$. All analyzed soil samples in these localities significantly exceeded the maximum limit $0.3 \mathrm{mg} \mathrm{kg}^{-1}$ set out by the Decree of the Ministry of the Environment (CZ) No. $153 / 2016$ and $0.5 \mathrm{mg} \mathrm{kg}^{-1}$ by Law No. 188/2003 (SK). In non-polluted localities, the mercury concentrations were in range $0.003-0.21 \mathrm{mg} \mathrm{kg}^{-1} \mathrm{Hg}$.

\section{3. Bioconcentration factors}

The highest bioconcentration factor (5.52-20.88) was calculated for mushrooms from the Boletaceae family, concretely for Boletus reticulatus 20.88. Siric et al. [9] state that the Boletacea family is able to accumulate several times more mercury than other mushroom species. According to Malayeri et al. [5] evaluation, Boletaceae belongs to the high metal accumulating mushrooms. 


\section{4. Hazard risk assessment}

Calculation of the Hazard index for human risk assessment revealed that A. bisporus, L. mole, R. integra and M. are the most risk mushroom species $(\mathrm{H}=1.20-6.35)$. These results highly correlate $(\mathrm{r}=0.91)$ with mercury amounts in suggesting that excessive consumption of mushrooms collected at contaminated sites is not appropriate for consumers. Similar results were investigated by Melgar et.al. [3].

\section{Conclusion}

The wild-growing mushroom species from unpolluted areas do not pose a health risk, but mushrooms pickled in contaminated areas can be the cause of human mercury intoxication. Mercury concentrations in the picked mushrooms were in the range from 0.11 to $9.52 \mathrm{mg} \mathrm{kg}^{-1}$ in the mushrooms from the Czech Republic and from 0.09 to $7.68 \mathrm{mg} \mathrm{kg}^{-1}$ in the mushrooms from Slovakia. A total of 9 mushroom samples exceeded the maximum limit $\left(5 \mathrm{mg} \mathrm{Hg} \mathrm{kg}^{-1} \mathrm{DW}\right) \mathrm{set}$ by previously valid decree No. 298/1997. Monitoring of mercury content in mushrooms is important for assessing the potential health risks for the consumers. The limits for mercury content in mushrooms in the Czech legislation should be restored.

\section{Acknowledgments}

This research was financially supported by the project Czech Science Foundation (19-11528S), by the project PROFISH CZ.02.1.01/0.0/0.0/16_019/0000869, which is financed by European Regional Development Fund in the Operational

Programme Research, Development and Education and The Czech Ministry of Education, Youth and Sports, and by CEITEC Mendelu.

\section{References}

[1] P. C. K. Cheung, "Mini-review on edible mushrooms as source of dietary fiber: Preparation and health benefits," Food Sci. Hum. Wellness, vol. 2, pp. 162-166, 2013.

[2] C. Sarikurkcu, J. Popović-Djordjević, M. H. Solak, "Wild edible mushrooms from Mediterranean region: Metal concentrations and health risk assessment," Ecotoxicol. Environ. Saf., vol. 190, pp. 110058, 2020.

[3] M. J. Melgar, J. Alonso, and M. A. García, "Mercury in edible mushrooms and underlying soil: Bioconcentration factors and toxicological risk," Sci. Total Environ., vol. 407, pp. 5328-5334, 2009.

[4] P. Pelcová, H. Dočekalová, A. Kleckerová, "Determination of mercury species by the diffusive gradient in thin film technique and liquid chromatography - atomic fluorescence spectrometry after microwave extraction," Anal. Chim. Acta, vol. 866, pp. 21-26, 2015.

[5] B. E. Malayeri, A. Chehregani, N. Yousefi, B. Lorestani, "Identification of the hyper accumulator plants in copper and iron mine in Iran," Pak. J. Biol. Sci., vol. 11, pp 490 - 492, 2008.

[6] K. Kannan, R. G. Smith, Jr., R. F. Lee, H. L. Windom, P. T. Heitmuller, J. M. Macauley, J. K. Summers, "Distribution of Total Mercury and Methyl Mercury in Water, Sediment, and Fish from South Florida Estuaries," Arch. Environ. Contam. Toxicol., vol. 34, pp. 109-118, 1998.

[7] Joint FAO/WHO Expert Committee of Food Additives, 2010: Summary and conclusions. In: Proceedings of the Seventy-second meeting, Rome. JECFA/72/SC, Food and Agriculture Organization of the United Nations World Health Organization. ISSN 0512-3054.

[8] M. Mikšik, "Rare and Protected Species of Boletes of the Czech Republic," Field Mycology, vol. 13, pp. 8-16, 2012.

[9] I. Širic, I. Kos, A. Kasap, A Kaic, V. Držai, L. Rakic, "Mercury accumulation by wild edible mushrooms," in 52 Croatian \& $12^{\text {th }}$ International Symposium on Agriculture, pp. $91-95$. 